ISSN 1989 - 9572

DOI: 10.47750/jett.2021.12.01.001

\title{
Culturological approach as a conceptual basis for renewing modern higher pedagogical education
}

Viktoriya Tusheva ${ }^{1}$ Anatoly Guba ${ }^{2}$ Kateryna Kalina ${ }^{3}$ Olha Temchenko ${ }^{4}$

\section{Journal for Educators, Teachers and Trainers, Vol. 12 (1)}

https://jett.labosfor.com/

Date of reception: 15 September 2020

Date of revision: 12 Dec 2020

Date of acceptance: 18 March 2021

Viktoriya Tusheva, Anatoly Guba, Kateryna Kalina, Olha Temchenko (2021). Culturological approach as a conceptual basis for renewing modern higher pedagogical education. Journal for Educators, Teachers and Trainers, Vol. 1w2(1). 1 - 7.

\footnotetext{
1,2Professor, Doctor of Pedagogical Sciences, H.S. Skovoroda Kharkiv National Pedagogical University, Kharkiv, Ukraine

${ }^{3} \mathrm{PhD}$ in Pedagogy, Assistant Professor, H.S. Skovoroda Kharkiv National Pedagogical University, Kharkiv, Ukraine

${ }^{4}$ Candidate of Pedagogical Sciences, Associate Professor, H.S. Skovoroda Kharkiv National Pedagogical University, Kharkiv, Ukraine
} 


\title{
Culturological approach as a conceptual basis for renewing modern higher pedagogical education
}

\author{
Viktoriya Tusheva ${ }^{1}$, Anatoly Guba ${ }^{2}$, Kateryna Kalina ${ }^{3}$, Olha Temchenko ${ }^{4}$ \\ ${ }^{1,2}$ Professor, Doctor of Pedagogical Sciences, H.S. Skovoroda Kharkiv National Pedagogical University, \\ Kharkiv, Ukraine \\ ${ }^{3} \mathrm{PhD}$ in Pedagogy, Assistant Professor, H.S. Skovoroda Kharkiv National Pedagogical University, Kharkiv, \\ Ukraine \\ ${ }^{4}$ Candidate of Pedagogical Sciences, Associate Professor, H.S. Skovoroda Kharkiv National Pedagogical \\ University, Kharkiv, Ukraine
}

\begin{abstract}
The article substantiates the prospects and productivity of the culturological approach, in the context of which culture is considered to be a source of content of higher pedagogical education and as a method of its research and design. Theoretical deduction of the concept of "culture" allows us to focus on the definitions that expand understanding of the essence of culture. The relationship between education and culture, a person and culture is revealed. The application of culturological approach in modern pedagogy is asserted, which provides a view of pedagogical phenomena and processes as cultural phenomena, requires certain ways of their cultural description, interpretation and construction, and focuses on a broad approach to culture and education in the context of general philosophical understanding. Probable changes in the content of pedagogical education in the context of the culturological approach, which cause adjustment of educational technologies, are outlined. At the normative level, it is manifested in the requirements to the content-related component as "containing culture" and "creating culture", of the procedural side, which differs in the integrity, integrative unity of all the components; management of educational and pedagogical activities on the principles of dialogue and mutual respect; educational space as a culturally appropriate, multicultural environment; learning technologies as human-dimensional, innovative, value-oriented.
\end{abstract}

Keywords: culture, culturological approach, cultural conformity, multiculturalism, cultural creativity, values, higher pedagogical education.

\section{PROBLEM STATEMENT}

Important changes in the state, related to the need for axiologization and humanization of socio-cultural space, have naturally led to the actualization of cultural problems of education in the minds of modern society and received its adequate reflection in higher pedagogical education.

The transition of modern education to a new cultural dimension and its cultural dominance have changed the traditional idea of the essence and functions of education in the context of cultural and culture-creating environment, cultural microcosm. Under modern socio-cultural conditions, education acquires a qualitatively new state, ceasing to be a rigidly determined system. This state is characterized by a different logic of existence, other patterns of development, namely self-development and self-construction, primarily due to the actualization of internal spiritual reserves. Thus, the improvement of higher pedagogical education in order to ensure its adequate compliance with the conditions of modern culture causes interest to the problem of the culturological approach applicatinon in pedagogy.

Content-related and procedural-functional aspects of cultural education were investigated by V.S. Bibler, Ye. V. Bondarevska, V. H. Butenko, B. S. Hershunskyi, S. I. Hessen, I. A. Ziaziun, N. B. Krylova, 
O. P. Rudnytska, V. V. Serikov, V. A. Slastonin, V.V. Tusheva, I. S. Yakymanska and others. However, the issue of identifying features of the culturological approach in the context of renewal of higher pedagogical education requires further scientific reflection and specification.

Consequently, the purpose of the article is to highlight various definitions of the concept of «culture», which expand the understanding of cultural education; to reveal the essence of the culturological approach as a conceptual basis and theoretical foundation in the transformation of the educational space, to identify the leading trends that determine the overall strategy of culturological education.

\section{MAIN RESEARCH MATERIAL PRESENTATION}

Theoretical realization of the natural character of relationships between education and culture, their isomorphic identity allows us to make assumptions about the prospects and productivity of applying culturological approach as a conceptual basis for the modernization of the content of higher pedagogical education. The outlined problem field represents a range of issues covering the problem of theoretical and methodological culturological integration of the concepts of «culture» and «education».

According to the analysis of scientific works, the apparatus of culturology acquires the status of metascience, which tries to understand the world of culture as a whole, to explain the essence of cultural phenomena, human existence and the historical purpose of human culture. The concept of «culturology», applied to the study of pedagogical reality, includes two main meanings: knowledge of culture and of theory of culture. This allows us to determine the main principles of the culturological approach, that means to consider culture as a source of content of higher pedagogical education and as a method of its research and design.

The application of the culturological approach in modern pedagogy involves a view of pedagogical phenomena and processes as a cultural phenomena, which requires certain methods of their cultural description, interpretation and construction, and focuses on a broad approach to culture and education in the context of their general philosophical understanding. The process of personality formation in the educational space from the standpoint of culturological approach requires a change in the nature of the pedagogical process towards emphasising its personality-oriented features.

It is interesting to consider the discovery of the essence of the concept of «culture» in the history of philosophy. Thus, the principle of «humanitarian» culture of the Renaissance according to which a «person is the creator of culture» was replaced by a rational-humanistic interpretation of the culture of the Enlightenment Pediod as the result and the purpose of a person's social and educational activities. In the context of modern philosophy, cultural and educational activities were considered as a necessary condition for a person's involvement in culture. In the future, the term «culture» will be used in the sense of education, awareness, a person's upbringing, and with these initial meanings, it will enter almost all the European languages, including Slavic languages.

The theoretical deduction of the concept of «culture» allows us to focus on definitions that expand the understanding of the essence of culture, fill it with new meaning and content, namely:

- culture is a qualitative definition of the phenomenon, which allows not only to identify and distinguish it from the others, but also to indicate the degree of formation, development and relative perfection;

- culture is the value significance and «content» of any phenomenon, which allows us to consider it in terms of involvement in the set of achievements in the fields of science, education, art, lifestyle; in this sense, culture itself becomes a social meta-value, combining values in their cultural-historical and national-cultural contexts;

- $\quad$ culture is a process and mechanism of both preservation and translation of values, and their constant generation and transformation in the field of cognition, communication and creativity;

- $\quad$ culture is the environment of socially significant merging of humanity and a space of free emergence of new elements of creative experience, its self-organization, self-development and self-renewal.

Considering culture in the coordinates of socio-cultural processes, the scientists (A. H. Zdravomyslova, N. S. Zlobin, L. N. Kohan, V. M. Mezhuiev, E. V. Sokolov, N. Z. Chavchavadze, etc.) come to the conclusion that culture exists as something dynamic that is constantly evolving and improving as the result of a person's creativity, and as cultural heritage, and as cultural creativity, culture is a product of labor in the highest and broadest sense of the word - a product of creative, transforming and self-transforming activity. Being characterized by creativity at any stage of development, culture, taken in its dynamic aspect, is impossible 
without creativity which is formative activity that generates something new and manifests itself in the form of original (creative) activity.

We consider the concept of «cultural creativity» as the functioning of cultural activity of individual existence, that is existance-in-culture, which is manifested in the generation of new cultural forms, meanings, values, as well as the introduction of existing cultural meanings into their own spiritual space through interpretation and evaluation. Cultural creativity represents the unity of the processes of «self» and the activation of an individual's essential forces in their own genesis of culture [5].

It is in the sense-bearing field of culturological approach that the uniqueness of a person is emphasized, the role of a human factor is strengthened, especially such persoanl qualities as one's identity and self-worth. A person's intellect and creative potential are considered the main productive force of society and education. According to the apt expression of M. S. Kahan, «a person becomes a direct culturogenic subject, who embodies oneself in culture, makes it a person's another identity and is formed by it» [7, p. 123]. Thus, culture acts as an internal impulse of personal development and a «mechanism» of this development provision.

It is important for us to understand a personal culture as the unity, the ensemble of socio-cultural qualities which do not only manifest themselves in quantitative but also in qualitative parameters which ensure productivity. In this sense, an individual's culture represents contextual and sense-bearing fullness of life, the degree of its harmonious development.

Interesting insights into the «dialogic nature of culture» are contained in the works by M. M. Bakhtin, who affirms the understanding of the two poles of dialogue, which is a microdialogue as the dialogue in the internal conversation which penetrates into our culture and thinking and a macrodialogue as the dialogue in the Great Time of Cultures, a dialogue of cultures. In this way, the value and spiritual spectra of different forms of culture converge in one cultural space, in one consciousness and thinking, requiring from a person not to have an unambiguous choice, but a constant spiritual connection, mutual transition, deep debate about «the eternal issues of existence». It is in this dialogue of different cultural senses one can find the essence of the present-time concept and modern logic of thinking.

The recognition of the need for dialogue of different cultures and the organization of conditions for their mutual influence and interaction is reflected in the formation of traditions of multicultural education, which is characteristic of modern socio-cultural space. Multiculturalism acts as a strategy of educational space and a meta-principle, according to which a person is the intersection of many cultures and therefore we can talk about the presence of several identities within the individual, that means an individual is multi- or polyidentical. Each person is a representative of a certain culture, cultural epoch, but this can be realized only in the process of communication-dialogue with people of different cultures (different theories and concepts), the result of which is an individual's free choice of spiritual values, lifestyle and thinking, his «self-determination within an individual's horizon» (Ye. V. Bondarevska).

Multiculturalism is manifested not only as a strategy of educational space and its meta-principle, but also as a peculiar property of a future teacher's consciousness, which aims to recognize the cultural connotation of different concepts, integrate knowledge on an interdisciplinary basis, apply polyparadigmatic approach in educational models. The transition to a polysystemic diversity of pedagogical theories and practices, their equality is a necessary condition in a situation of free choice of a teacher's own strategy, pedagogical technologies and teaching methods, understanding of pedagogical theories as an interconnected number of different «logics» that exist and enrich in free interaction .

Culturological education is aimed to form an image of culture as the system of personal, ethnic, national and universal human values and promote the ascent from a person of culture to a person as an individual. Education carried out within the culturological education is aimed at the formation of a person's value orientations and cultural self-identification. It is the axiological characteristics of pedagogical reality that reflect its humanistic meaning, human dimension, on the one hand, and on the other hand, an individual's value orientations are reflected in the moral and universal human values, which are the highest manifestation of the target determination of the activity of a teacher's personality.

Modern understanding of education (V.P. Andrushcheko, Ye.V. Bondarevska, I.A. Ziaziun, V.H. Kremen, N.B. Krylova and others) actualizes its consideration as a socially-conditioned formation of a person which acquires his personal image, determined by the current state of cultural life. However, education does not appear as an unambiguously predetermined ascent to the necessarily outlined pattern, in which the perception of the essence 
of a person is embodied, but also as a continuous realization and self-realization in the space of culture and society. As V. S. Bybler points out, the content of culture must be re-understood. Inside of it there must be the education of a person of culture, a person who is not only able to be involved into existing forms of thinking and activity, but to reformulate their principles, combined with different cultural meanings [2].

The purpose of higher pedagogical education as a sociocultural phenomenon is to reorient its cultural function, which should be a priority, meet new positive trends in sociocultural development, focus on the following cultural dominants of modernity: anthropocentrism, humanism, democracy, spirituality, morality, variability, encyclopedic and integrative character. This understanding of modern education corresponds to the trends and dynamics of modern culture, changes the nature of action in the educational and pedagogical space and expands the boundaries of its design, helping its subjects to set and solve value-related, innovative, and sense-searching tasks.

The leading trends that determine the overall strategy in the field of culturological education and its content, can be outlined as:

- reproduction of cultural patterns and norms in educational structures. These patterns and norms design the elements of the cultural environment, the condition of which is the integration of education into culture and vice versa - culture into education;

- the reflection of natural connections, according to which not only the level of cultural development determines the level of educational development, but also education becomes a source of development of culture, a generator of new cultural forms, and thus requires a person to be highly-educated;

- taking into account the laws and features of culture, the specification of which determines a certain type of human culture (as the unity and harmony of all its components), affects the procedural side of education as a cultural act, leading to the realization of important socio-cultural functions (inculturation, socialization, cultural patterns transition, etc.);

- strengthening the value component and sense-bearing components of culture, the integral unity of creative, spiritual, moral, social and technological components of the content of education in the system of cognitive, value and regulatory coordinates;

- the realization of the ideas of personality-oriented paradigm of humanistic type, the actualization of new values in pedagogical practice and cultural-educational environment. The values are related to personal self-development, self-organization, self-regulation, self-reproduction, creativity as a way of a person's self-realization [6].

The principle of cultural conformity becomes a methodologically significant principle of cultural education (S.I. Hessen, S.Iu. Kurhanov, Yu.M. Lotman, $\quad$ B.M. Nemenskyi, H.H. Shpet, etc.). Thus, according to S.I. Hessen, the development of culture and the development of education are the processes which largely take place in parallel, synchronically and interconnectedly. The purpose of life of modern cultural society is defined by the scientist «the purpose of education», emphasizing that «there is exact correspondence between education and culture» [3, p. 25]. Real education is not about passing on a ready-made cultural content to a new generation, but only about informing it of a movement, continuing which the new generation could build its own new content of culture.

The relationship between education and culture is manifested primarily through a person who is a systemic connecting link between the cultural and educational systems. Distinguishing the subsystem «person» as a separate system element is a fundamental and essential point, which emphasizes the fact that in the holistic humanitarian cultural and educational system, a person serves as a subject in relation to culture as well as in relation to education. This gives grounds to consider the categories «education», «a person» and «culture» as a single humanitarian cultural and educational system, which can serve as a methodological model for the development of culturological educational approaches, concepts, and paradigms.

Culture and personality are the concepts that do not relate externally. They relate internally. A personality operates in a cultural environment, which, in turn, fills the personality, becoming its system-integrative formation. It is uniqueness, originality, creative self-creation of oneself and the world around oneself that make up the most essential features of human culture as a person.

In this aspect, the culturological approach intersects with the anthropological one, as the one which presupposes an organic interrelation between a person, society and the Universe and is manifested in a set of approaches to 
the problem of a person in the context of various philosophical systems of understanding the world and its evolution, dominance of «subjective pole» in scientific cognition. In this sense, education is understood as an anthropic practice of culture, a factor of personality development, which appeals, first of all, to humanistic categories. Understanding creativity as an attributive quality of personality and activity, accompanied by the complication of the whole cultural, spiritual «field» of personality, is fully consistent with the desire to establish the cultural and anthropological context of culture, to ensure the social significance of creative activity as a form of human identity, the manifestation of a person's spirituality [5].

The statement about the improvement of the mechanism of a person's socialization and inculturation by means of education is important for our research. Thus, in the cultural-historical theory by L. S. Vygotsky, inculturation appears as interiorization, in the process of which a person learns the values of culture, his internal world is formed. Considering education as a purposeful process of a person's inculturation fills the classical principle of cultural expediency of education, formed by A. Diesterweg in such a way that culture should reveal the potential possibilities of a process of a person's formation. The process of a person's separation in the course of inculturation unfolds as self-concept formation; and the level of sociality, the level of awareness and adequacy of a person's system of ideas about oneself, spiritual and moral orientation of one's attitudes to oneself are determined by one's individual culture. In the scheme of self-concept, a person appears to be a subject of self-creation, self-construction from the inside, from one's own culture and sociality. Thus, the stimulation and development of a person's self-concept, one's cultural and social image in the educational process become the main tasks of culturological education.

The sociological approach allows us to comprehensively consider the dialectic of a person's social integration and individualization, presenting this process as an interaction, on the one hand, of objective, external factors of «social environment», «social environment» that allow a person to gain sociality from the inside; and, on the other hand, as a person's activity as a result of which the relations and contradictions in the system «society - a person» are optimized, a person's inner spiritual world which represents the unity of the objective and the subjective is formed. The sociological concept of culture is reflected in the understanding and creation of cultural and educational environment as a socio-cultural system, which is a form of translation and reproduction of cultural norms, values, ideas, types of behaviour that create conditions for optimal existence in society and culture; as a space for generating cultural and sociological ideology, which combined with its bearers will grow and «develop» in culture. As V. S. Stopin points out, culture is the genome of social life, and for a new type of society to emerge, a new cultural matrix must appear.

An integrative, complex method of designing educational systems acquires priority importance within the culturological approach. Its implementation is based on the principle of integrity, which becomes dominant. Features of the principle of integrity are revealed in the following conceptual provisions:

1) a holistic methodological approach is considered to be the unity of the didactic system and process, which serves as a criterion of methodological unity;

2) a holistic view of culture acts as the unity of its spiritual, social and technological components, the dialectic of the relationship between education and culture, the unity of the axiological basis of culture in the form of its values systematic organization;

3) a person's holistic representation as a cultural and anthropological representation of a person's essence (a complete individual), the relativity of the complete person in his incompleteness, which determines the driving forces of his self-development and self-creation;

4) the integrity of the content of education reflects the internal inseparability of its elements in the context of culture, a holistic pedagogical system forms the unity of its subsystems (goals, principles, methods, tools), filled with a single culturological, culture creating content;

5) integrity as a quality of the pedagogical process characterizes the highest level of its development, which is defined by unity, interaction and interconnection of all its components. A holistic personality can be developed only in a holistic pedagogical process.

Thus, the recognition of the integrity of culture, education and personality, ways and means of their formation, dynamization of development, understanding the priority of cultural functions of education involves the development of new theoretical and methodological approaches in pedagogical education.

Conclusions. Thus, the culturological approach represents the theoretical basis of modern higher pedagogical education, the specific scientific methodology of its transformation, the main strategic direction of its renewal. 
Let's outline possible changes in the content of pedagogical education in the context of the culturological approach, which leads to the adjustment of educational technologies. At the normative level, this is manifested in the requirements for the content-related component as «containing culture» and «creating culture», which aims to find new content and meanings in pedagogical education; procedural side, characterized by integrity, integrative unity and interaction of all the components; management of educational and pedagogical activities on the principles of dialogue, mutual respect, trust, considering personal and individual characteristics of the subjects of education; educational and pedagogical space as a culturally expedient, multicultural, humanistic environment; learning technologies being human-dimensional, innovative, value-oriented; means of diagnostics and monitoring the quality of pedagogical education, which objectively and differently allow us to assess the level of professional and personal development of subjects and objects of the pedagogical process.

\section{REFERENCES}

1. Andruschenko V. P. (2008) Rozdumi pro osvitu: Statti, narisi, interv'yu [Reflections on education: Articles, essays, interviews]. K.: Znannya Ukrayini, 819 p. (in Ukrainian).

2. Bibler V. S. (2008) Ot naukoucheniya - k logike kulturyi: Dva filosofskih vvedeniya v dvadtsat pervyiy vek [From Epistemology to Logic of Culture ]. M.: Politizdat, 413 p. (in Russian).

3. Gessen S. I. (2005) Osnovyi pedagogiki. Vvedenie v prikladnuyu filosofiyu [Fundamental Concepts of Pedagogics]. M.: Shkola - Press. 448 (in Russian).

4. Mezhuev V. M. (2006) Ideya kulturyi. Ocherki po filosofii kulturyi/ V. M. Mezhuev [Idea of culture. Essays on philosophy of culture]. M.: Progress-Traditsiya, 408 p. (in Russian).

5. Tusheva V. V. (2018) Kulturologichna paradigma v umovah modernizatsiyi mistetskoyi osviti: kontseptualni ideyi ta metodologichni orientiri [Culturological paradigm in the conditions of modernisation of artistic education: conceptual ideas and methodological reference-points]. Naukovi zapiski / Red. kol.: V. F. Cherkasov, V. V. Radul, N. S. Savchenko ta in. Vipusk 163. SerIya: pedagogIchnI nauki. Kropivnitskiy: RVV TsDPU Im. V. Vinnichenka, P. 39-43 (in Ukrainian).

6. Tusheva V. V. Sutnist ponyattya «kultura», yogo osnovni definitsiyi [Essence of concept «culture», him basic definitions].Teoretiko-metodologichni zasadi formuvannya naukovodoslidnitskoti kulturi maybutnogo vchitelya v protsesi profesiynoyi pidgotovki: Monografiya / V. V. Tusheva; UMO NAPN Ukrayini HarkIv: Vidavnitstvo «Fedorko», 2013. P. $32-51$ (in Ukrainian).

7. Filosofiya kulturyi. Stanovlenie i razvitie / Pod red. M. S. Kagana, Y. V. Petrova, V. V. Prozerskogo (2008) [Philosophy of Culture. Becoming and Development]. SPb: Izdatelstvo «Lan». 448 p. (in Russian). 